\title{
Recanalization of a Large Supraclinoid Carotid Aneurysm Via Elicited Vertebral Artery-Internal Carotid Artery Anastomosis: A Case Report
}

\author{
Vertebral Arter Internal Karotid Arter Anastomozu Yoluyla Bir Büyük \\ Supraklinoid Karotid Anevrizmasinın Tekrar Kanalizasyonu: \\ Bir Olgu Sunumu
}

Kimihiro NAGATANI ${ }^{1}$, Nobusuke TSUZUKI ${ }^{2}$, Hiroshi KAGEYAMA ${ }^{2}$, Katsuji SHIMA ${ }^{1}$

${ }^{1}$ National Defense Medical College, Department of Neurosurgery, Tokorozawa, Saitama, Japan

${ }^{2}$ Kuki General Hospital, Department of Neurosurgery, Kuki, Saitama, Japan

Corresponding Author: Kimihiro NAGATANI / E-mail: naval.kimi@gmail.com

\begin{abstract}
Proximal ligation of the internal carotid artery (ICA) with high-flow bypass is one of the surgical strategies for treating large, unclippable ICA aneurysms. We encountered a rare case of recanalization of a large ICA aneurysm that disappeared after high-flow bypass surgery, and subsequently reappeared via an elicited vertebral artery (VA)-ICA anastomosis (anastomosis between the anterior meningeal artery branching from the right VA, and the ascending pharyngeal artery branching (APA) from the right ICA). To the best of our knowledge, this is the first case report describing angiographical recurrence of a large ICA aneurysm after the surgery. Periodic long-term follow-up by neuroimaging may be necessary after this surgery, particularly in cases of ICA proximal ligation with the ICA aneurysm, when the APA has not been clearly identified as a branch from the ipsilateral external carotid artery on the preoperative angiogram.
\end{abstract}

KEYWORDS: Anterior meningeal artery, Ascending pharyngeal artery, Cerebral revascularization, Internal carotid artery occlusion, Intracranial aneurysm

öz

Yüksek akım bypasslı internal karotid arter (IKA) proksimal ligasyonu büyük ve kliplenemeyen İKA anevrizmalarını tedavi etmek için cerrahi stratejilerden biridir. Yüksek akımlı bypass cerrahisinden sonra kaybolup daha sonra bir vertebral arter (VA) veya IKA anastomozu (sağ VA'dan dallanan anterior meningeal arter ile sağ İKA'dan dallanan asendan faringeal arter (AFA) arasında anastomoz) yoluyla tekrar beliren nadir bir büyük İKA anevrizması kanalizasyonu olgusu saptadık. Bildiğimiz kadarıyla bu rapor cerrahiden sonra büyük bir IKA anevrizmasının anjiyografik olarak tekrar oluşmasını tanımlayan ilk olgu raporudur. Bu cerrahiden sonra nörogörüntüleme ile düzenli uzun süreli takip özellikle IKA anevrizmasıyla birlikte İA proksimal ligasyonu yapılan ve AFA'nın preoperatif anjiyogramda ipsilateral eksternal karotid arterin bir dalı olarak açıkça tanımlanmadığı durumlarda gerekebilir.

ANAHTAR SÖZCÜKLER: Anterior meningeal arter, Asendan faringeal arter, Serebral revaskülarizasyon, İnternal karotid arter oklüzyonu, intrakraniyal anevrizma

\section{INTRODUCTION}

Proximal ligation of the internal carotid artery (ICA) with highflow bypass is one of the surgical strategies for treating a large unclippable, or a giant, ICA aneurysm. The principle underlying this treatment is that the surgical excision of the carotid artery will decrease blood pressure distal to the ligation, potentiate thrombosis, and minimize the risk of aneurysm growth and rupture (1). We herein report a pitfall of this surgery: the blood reflowed into the aneurysm via elicited vertebral artery (VA)ICA anastomosis.

\section{CASE REPORT}

In December 2003, a 67-year-old healthy woman presented with reduced visual acuity of the right eye. Digital subtraction angiography (DSA) revealed a large aneurysm, $18 \mathrm{~mm}$ in diameter, at the supraclinoid portion of the right ICA (Figure $1 \mathrm{~A})$. The balloon occlusion test (BOT) showed poor ischemic tolerance. Furthermore, the BOT showed no filling of the aneurysm and no flow in the right ICA. In February 2004, proximal ligation of the right cervical ICA with the ipsilateral external carotid artery (ECA)-ICA high-flow bypass, and a superficial temporal artery (STA)-middle cerebral artery (MCA) bypass were performed. Postoperative DSA showed no filling of the aneurysm, and good patency of each bypass (Figure $1 B, C)$. Postoperative computed tomography showed that the aneurysm was completely thrombosed (Figure 1D). Her visual acuity did not worsen, and she was discharged without any new neurological deficit. Follow-up magnetic resonance 


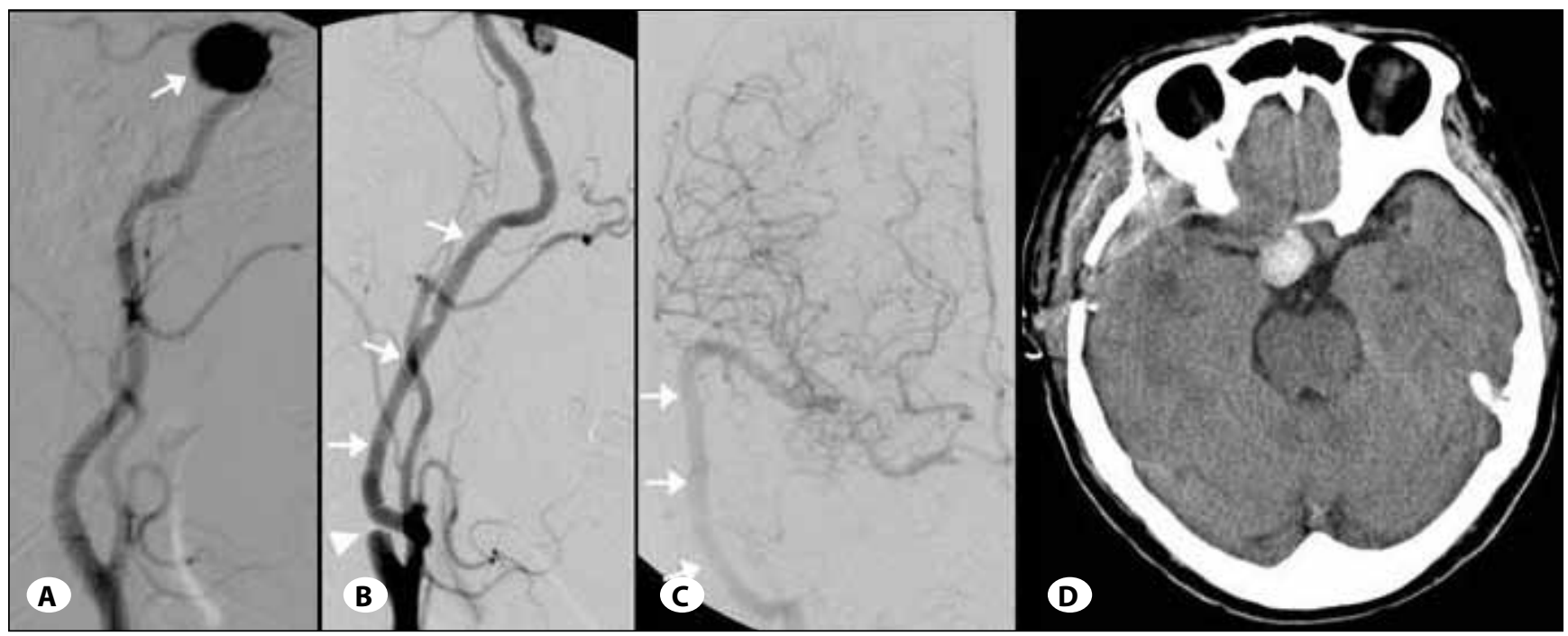

Figure 1: A) Preoperative digital subtraction angiogram of the right common carotid artery showing a large supraclinoid carotid aneurysm (arrow). The ascending pharyngeal artery is not visible. B, C) Postoperative digital subtraction angiogram of the right common carotid artery showing good patency of the high-flow bypass (arrows). Note that the right cervical internal carotid artery is occluded (arrowhead), and the aneurysm is not visualized. D) Postoperative computed tomography showed that the aneurysm was completely thrombosed.
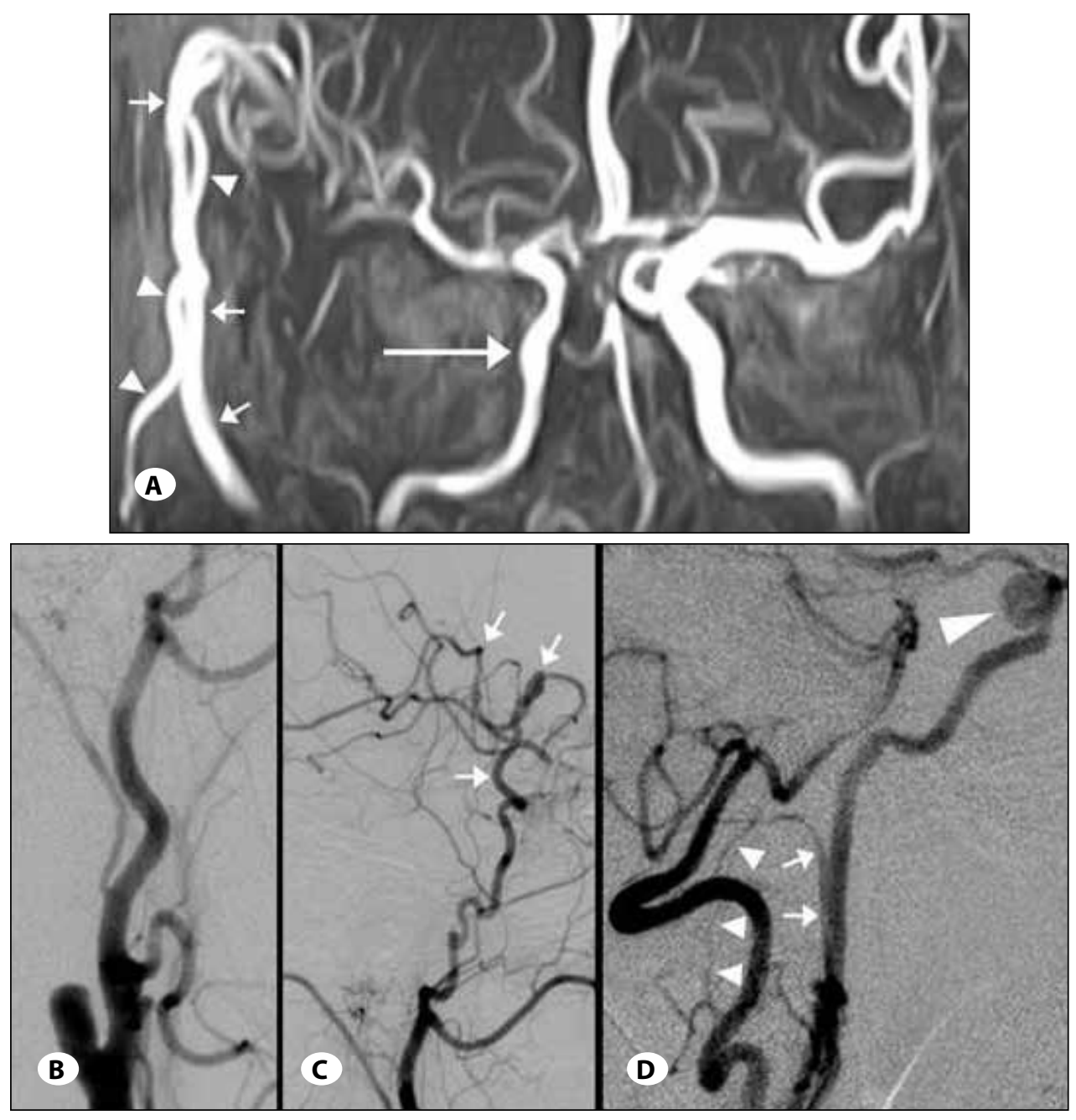

Figure 2: A) Follow-up magnetic resonance angiography obtained 3 years after the surgery shows good patency of each bypass (small arrows: ECA-ICA high-flow bypass, arrowheads: STA-MCA bypass), and demonstrates that flow in the right ICA gradually increases (large arrow).

B, C) Digital subtraction angiography of the right common carotid artery obtained 4 years after surgery. The high-flow bypass completely disappears (B), and the superficial temporal arterymiddle cerebral artery bypass (arrows) continues to show good patency (C).

D) Digital subtraction angiogram of the right VA obtained 4 years after the surgery. Blood flow from the right VA to the right ICA is observed via anastomosis between the anterior meningeal artery (small arrowheads) of the right $\mathrm{VA}$, and the ascending pharyngeal artery (arrows) of the right ICA. As a result, the supraclinoid aneurysm (large arrowhead) of the right ICA reappears. 
angiography (MRA) showed good patency of the ECA-ICA high-flow bypass until 3 years after the surgery. Moreover, follow-up MRA also revealed that flow in the right ICA gradually increased (Figure 2A). Follow-up DSA after 4 years of surgery showed good patency of the STA-MCA bypass (Figure 2C), but complete obliteration of the ECA-ICA highflow bypass (Figure 2B). Instead, blood flowed from the right VA to the right ICA, above the ligation, via the anastomosis between the anterior meningeal artery (AMA) of the right VA and the ascending pharyngeal artery (APA) of the right ICA (Figure 2D). As a result, the supraclinoid aneurysm of the right ICA reappeared (Figure 2D). The size and shape of the aneurysm was similar to the one before surgery. Her visual acuity did not worsen, and she did not wish to undergo any further treatment for the recurring aneurysm.

\section{DISCUSSION}

Kagawa et al. previously reported that rapid antegrade recanalization of the ICA occurred after ICA proximal ligation for the treatment of intracavernous carotid artery aneurysm in young woman who had nevi (6). They reported that this phenomenon occurred as a result of the development of unusual collateral pathways, probably facilitated by angiodysplasia. However, this is a rare case report describing the recanalization of a large supraclinoid carotid aneurysm via elicited AMA-APA (VA-ICA) anastomosis in a patient without any signs of vascular abnormalities, after ICA proximal ligation with the ECA-ICA high-flow bypass surgery.

The APA is the remnant of the embryologic artery of the third brachial arch, and it normally arises from the posterior wall of the proximal ECA trunk. However, the APA may arise from the ICA (2). Some investigators have reported that the APA branching from the ICA may act as a collateral pathway in patients with ICA occlusion $(8,10)$. The AMA is a branch of the VA, which supplies the dura in the foramen magnum and the upper cervical region (7). The AMA arises from the VA between the C 2 and C 3 levels, and forms an arcade above the apex of the odontoid process with its contralateral mate $(7,9)$. It anastomoses with the hypoglossal branch from the APA, which passes through the hypoglossal canal $(3,7,9)$. This anastomosis (pharyngovertebral anastomosis) is well known, because it may cause palsy of the lower cranial nerves in intravascular embolization for lesions fed by the AMA (9). In our case, preoperative BOT showed no filling of the aneurysm and no flow in the right ICA. It was therefore impossible for us to foresee this potential anastomosis during the original decision-making process. Because the BOT showed poor ischemic tolerance, we performed a double-bypass method (STA-MCA bypass and ECA-ICA high-flow bypass) to reduce the risk of ischemic complications associated with revascularization of the ICA $(4,5)$.

Our speculation of the pathogenesis was as follows: (a) Blood flow reduction in the right ICA after the proximal ligation led to potential anastomosis between the AMA branching from the right VA, and the APA branching from the right ICA. (b) The collateral blood supply via this AMA-APA anastomosis gradually increased. (c) When this collateral blood supply reached the level of brain tissue demand, the ECA-ICA highflow bypass collapsed and was obliterated. Follow-up MRA actually showed good patency of the ECA-ICA high-flow bypass until 3 years after the surgery, and demonstrated that flow in the right ICA gradually increased. These facts deny the possibility that the high-flow bypass was occluded, possibly as a result of a technical failure prior to the establishment of collateral circulation via VA-ICA anastomosis, and therefore support our speculation. (d) The patency of the STA-MCA bypass was nonetheless maintained because the collateral blood supply via this bypass was adequate to meet the demand of local brain tissue after the surgery.

In this case, we performed proximal ICA ligation for treating a large supraclinoid carotid aneurysm because we expected at that time that the aneurysm would be thrombosed. However, the aneurysm was finally recanalized. At present, we consider that it might be better to perform trapping of the parent artery by surgical and/or endovascular procedure in order to avoid aneurysm recanalization like this case.

\section{CONCLUSIONS}

The combination of proximal ICA ligation with high-flow bypass surgery may not be a curative surgery for a large ICA aneurysm. Therefore, periodic long-term follow-up by neuroimaging may be necessary after this surgery, particularly in cases of ICA proximal ligation with the ICA aneurysm, when the APA has not been clearly identified as a branch from the ipsilateral external carotid artery on the preoperative angiogram.

\section{REFERENCES}

1. Barrow DL, Cawley CM: Therapeutic carotid occlusion: Indications and potential complications. Clin Neurosurg 46: 392-409, 2000

2. Hacein-Bey L, Daniels DL, Ulmer JL, Mark LP, Smith MM, Strottmann JM, Brown D, Meyer GA, Wackym PA: The ascending pharyngeal artery: Branches, anastomoses, and clinical significance. AJNR Am J Neuroradiol 23: 1246-1256, 2002

3. Haffajee MR: A contribution by the ascending pharyngeal artery to the arterial supply of the odontoid process of the axis vertebra. Clin Anat 10: 14-18, 1997

4. Hongo K, Horiuchi T, Nitta J, Tanaka Y, Tada T, Kobayashi S: Double-insurance bypass for internal carotid artery aneurysm surgery. Neurosurgery 52: 597-602, 2003

5. Ishikawa T, Kamiyama H, Kobayashi N, Tanikawa R, Takizawa K, Kazumata K: Experience from "double-insurance bypass." Surgical results and additional techniques to achieve complex aneurysm surgery in a safer manner. Surg Neurol 63: 485-490, 2005

6. Kagawa K, Shimizu H, Matsumoto $Y$, Watanabe M, Tominaga T: Rapid revascularization after therapeutic parent artery occlusion for a large intracavernous carotid artery aneurysm. Neurol Med Chir (Tokyo) 47: 559-563, 2007 
7. Lasjaunias $\mathrm{P}$, Moret J, Théron J: The so-called anterior meningeal artery of the cervical vertebral artery. Normal radioanatomy and anastomoses. Neuroradiology 17: 51-55, 1978

8. Pelz DM, Fox AJ, Vinuela F, Dion JE, Agnoli L: The ascending pharyngeal artery: A collateral pathway in complete occlusion of the internal carotid artery. AJNR Am J Neuroradiol 8: $177-178,1987$
9. Shimizu S, Garsia AS, Tanriover N, Fujii K: The so-called anterior meningeal artery: An anatomic study for treatment modalities. Interv Neuroradiol 10: 293-299, 2004

10. Ueda M, Morinaga K, Matsumoto $Y$, Omiya N, Mikami J, Satou $\mathrm{H}$, Inoue $\mathrm{Y}$, Okawara S, Miyasaka K: Internal carotid artery stenosis and external carotid artery occlusion with unusual extracranial collateral pathway: Case report. No Shinkei Geka 19: 451-454, 1991 (Japanese) 